\title{
Changes in the structure of Melolonthidae (Coleoptera: Scarabaeoidea) assemblages along a temporal gradient in a natural reserve in Chaco, Argentina
}

\author{
Mario G Ibarra Polesel* (D) and Miryam P Damborsky (D) \\ Facultad de Ciencias Exactas y Naturales y Agrimensura, Universidad Nacional del Nordeste, Avda. Libertad 5470, 3400 \\ Corrientes, Argentina.
}

\begin{abstract}
Melolonthidae beetles have been proposed as bioindicators because of their important role in the ecosystem and sensitivity to disturbance processes. However, the assemblage structure of these species in Argentina is unknown. In this study, the first attempt at determining Melolonthidae diversity, we analysed the abundance and diversity of the Melolonthidae assemblage and the species richness turnover over a period of three years. We collected samples in a gallery forest relict of a small protected area in which two light traps were installed. We collected a total of 474 specimens belonging to 38 species, two of which are new records for Argentina. The assemblage was characterised by numerous rare species, and the richness and diversity as well as the distribution of species abundance varied over the three years of the study. Replacement values varied based on the similarity indices that were used. Selected environmental variables (relative humidity, temperature and rainfall) were correlated with the richness and the abundance of the beetles. Our results suggest that the community of Melolonthidae could be considered dynamic, even over relatively short periods of time. Rare species play a major role in analyses of the similarity between assemblages and could suggest exaggerated turnover values. The high richness of the study area may be due to its good state of preservation or to its small area, which allows the entry of species from surrounding environments, showing how complex and fluid the Melolonthidae community can be in small patches of forest.
\end{abstract}

Key words assemblage, northeastern Argentina, phytophagous beetle, protected area, richness, turnover.

\section{INTRODUCTION}

In Argentina, the province of Chaco is one of the most affected by deforestation. In the last 25 years, Chaco has suffered from an $11 \%$ reduction in forest area (Cuadra 2012). Therefore, protected areas are necessary for maintaining the biodiversity of native environments. The Reserva Natural Educativa Colonia Benítez (RNECB) is protected by the National Parks Administration (Chebez 2005), providing a reference area where the preservation of the native biota diversity is ensured. The RNECB is located within the Ramsar Site Humedales Chaco, and the landscape is composed of complex freshwater environments, aquatic vegetation, grasslands and gallery forests.

Insects are significant components of great importance in many ecosystems and are useful as biodiversity indicators and conservation monitoring strategies (McGeoch et al. 2002). As it is impossible to work with all insects in an area, effort has focused on certain groups recognised for being good indicators of ecosystem quality, mainly because of their sensitivity to changes caused by human intervention (Noss 1990; Brown 1997). Among these, Scarabaeoidea is one of the most recognised and widely used groups due to their high diversity (Halffter \& Favila 1993; Favila \& Halffter 1997; Morón 1997).

Melolonthidae (sensu Endrödi 1966) is composed of the subfamilies Dynastinae, Rutelinae and Melolonthinae (Cherman \& Morón 2014). The family Melolonthidae is present in all

*mario.ibarrapolesel@gmail.com biogeographic regions, and in the Neotropical region, it includes 3450 species belonging to 300 genera (Morón 1997). While some species are agricultural pests (Frana 2007; Steinbauer \& Weir 2007; Cherman et al. 2014), most are beneficial organisms, as they fulfil a variety of important roles in ecosystem function: they are primary and secondary consumers, decomposers and pollinators, as well as providing food for insects and vertebrates. Because they are susceptible to environmental disturbances (Moron \& Deloya 1991; Otavo et al. 2013; Pardo-Locarno 2013), Morón (1997) proposed Melolonthidae as a bioindicator taxon in Neotropical areas, focusing mainly on the subfamilies Dynastinae and Rutelinae.

Studies related to Melolonthidae in Argentina are limited to species whose larvae are of agricultural importance (Frana 2007; Bonivardo et al. 2013). There are no current inventories available, and the structure and composition of the assemblages in the different eco-regions are unknown. Therefore, the species richness within the family may be underestimated. These types of ecological studies are necessary for assessing the conservation status of protected areas and for proposing management strategies (Noss 1990; Favila \& Halffter 1997; Braby \& Williams 2016).

Diversity has been separated into different components (Whittaker 1972). Alpha diversity can be defined as diversity at the local scale, with species richness being one of the most studied measures of diversity (Magurran 2004). Various overlapping definitions and concepts have been proposed to define beta diversity (Anderson et al. 2011). In particular, the turnover of species over time is described as temporal beta 
diversity. Research on species diversity changes over temporal scales is essential to understanding community structures and can reveal patterns about the permanence of communities over time (Whittaker 1972; Anderson et al. 2011; Calderón-Patrón \& Moreno 2012).

Long-term studies on Melolonthidae are scarce. Allsopp and Logan (1999) and Buss (2006) studied their flight patterns and abundances over several years, and Moron and Deloya (1991) discussed some issues concerning temporal turnover. Other related taxa (Scarabaeidae: Scarabaeinae) have been studied, and significant changes in the assemblages over time have been indicated in multiple studies (Howden \& Howden 2001; Quintero \& Roslin 2005; Halffter et al. 2007; Escobar et al. 2008; Agoglitta et al. 2012).

This study aimed to analyse the richness, diversity and turnover rate of the Melolonthidae assemblage in the RNECB over a period of three years. We posed the following questions: (1) How much do the richness, diversity and composition of the assemblage change over a three-year period? (2) What is the turnover rate of species among the sampling years in an area without human disturbance? (3) Is there an environmental variable that influences the richness and abundance of melolonthids?

\section{MATERIALS AND METHODS}

\section{Study area}

The study was conducted in a small protected area (7 ha), in the RNECB $\left(27^{\circ} 19^{\prime} 04^{\prime \prime} \mathrm{S}\right.$ - 58 $\left.57^{\prime} 00^{\prime \prime} \mathrm{W}\right)$, located in Colonia Benitez, Primero de Mayo Department, Chaco Province, Argentina (Fig. 1). The study site is surrounded by modified areas, such as patches of secondary forest and pastures for livestock.

The climate of the region is subtropical, and according to historical data (1991-2013), the average annual temperature is $21^{\circ} \mathrm{C}$, with an absolute maximum of $42^{\circ} \mathrm{C}$ and an absolute minimum of $-3^{\circ} \mathrm{C}$. The rainfall pattern shows maximum values in the autumn and spring, with an average annual rainfall of $1300 \mathrm{~mm}$ (Basterra et al. 2013). The soils in the area can be defined as sedimentary of fluvial and lacustrine origin and consisting of fine material. The soils are characterised by a silty loam texture, an average concentration of organic matter and high phosphorus content, and they are strongly acidic (Ledesma 1995).

Biogeographically, the area is located in the Neotropical region, a sub-region of the Eastern Chaco or Humid Chaco. Despite its small size, the RNECB contains a high richness of approximately 280 plant species (Ginzburg \& Adámoli 2006). The studied vegetation unit corresponds to a gallery forest, composed of Enterolobium contortisiliquum (timbó), Handroanthus heptaphyllus (lapacho negro), Peltophorum dubium (ibirá pitá), Astronium balansae (urunday), Phytolacca dioica (ombú), Myrcianthes pungens (guabiyú), Prosopis alba (algarrobo blanco), Prosopis nigra (algarrobo negro), Caesalpinia paraguariensis (guayacán) and Chrysophyllum gonocarpum (aguaí) among other species (Chebez 2005).

\section{Field activities}

We collected the melolonthids in a gallery forest relict of the RNECB for three consecutive years (2010-2012), both in spring (September 21st to December 20th) and in summer (December 21st to March 20th), because these two seasons correspond to the periods of higher adult activity (flight and reproduction).

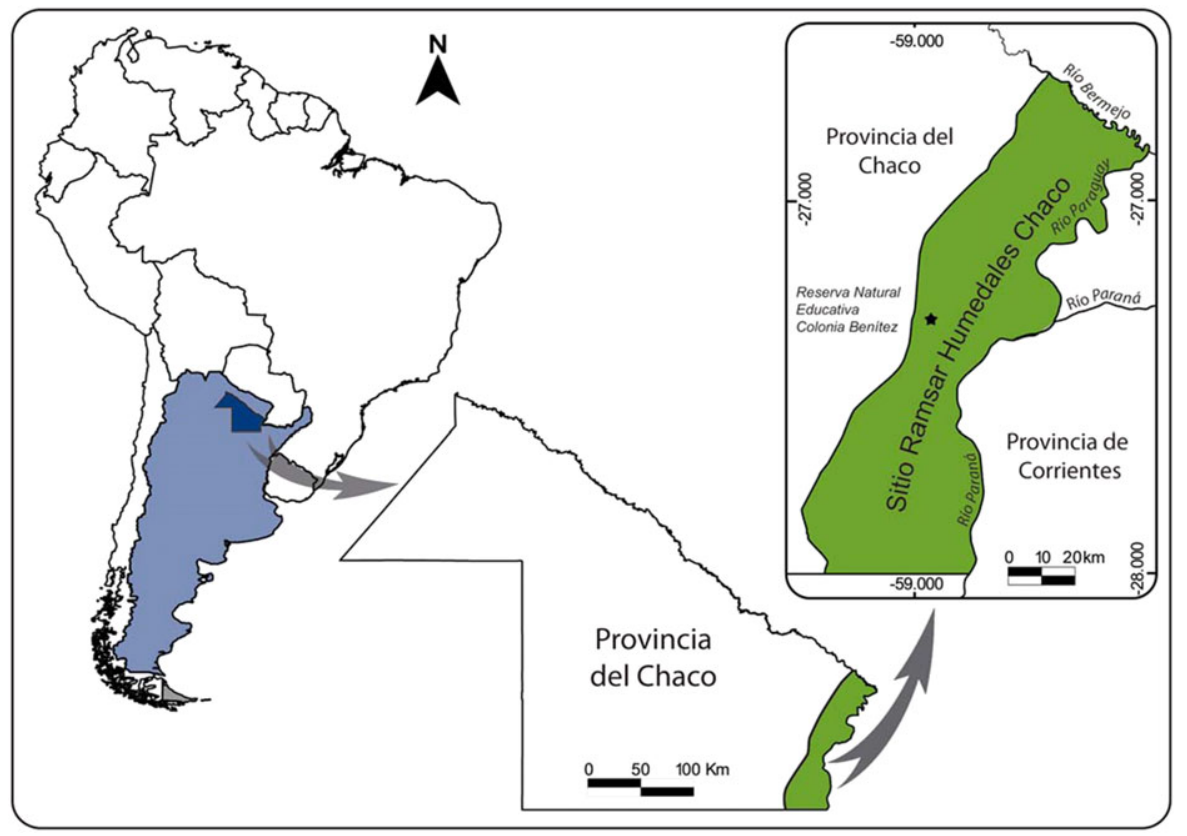

Fig. 1. Location of Colonia Benítez Educative Natural Reserve. Chaco Province, Argentina. [Color figure can be viewed at wileyonlinelibrary.com] 
On each sampling date, two light trap screens $(2 \mathrm{~m} \times 1.50 \mathrm{~m})$ were placed in the same locations. To optimise the attraction radius of the light, the traps were installed in clearings inside the forest. Each trap was illuminated with two fluorescent tubes of $20 \mathrm{~W}$, one with white light and the other with ultraviolet light. The traps were separated by a distance greater than $50 \mathrm{~m}$ and remained active for four hours after sunset. Light traps are one of the most commonly employed methods in this type of study (Ronqui \& Lopes 2006; Steinbauer \& Weir 2007; García-López et al. 2010). The individuals captured were killed with ethyl acetate vapour.

Temperature (maximum, minimum and average), relative humidity and rainfall records were provided by the weather station of Instituto Nacional de Tecnología Agropecuaria (INTA) Colonia Benítez. During the collection period, the highest values of annual rainfall were recorded in 2010 $(1517 \mathrm{~mm})$, followed by $2011(1217 \mathrm{~mm})$ and 2012 $(1178.6 \mathrm{~mm})$. The absolute maximum temperatures (37.5 and $40.5^{\circ} \mathrm{C}$ ) were recorded in November and December. During the periods of study, the relative humidity averaged $72 \%$, with a maximum of $96 \%$ and a minimum of 56\% (INTA 2015).

\section{Laboratory activities}

Individuals were identified using specific taxonomic keys and compared with the material in the collections of the Museo Argentino de Ciencias Naturales 'Bernardino Rivadavia' (MACN). Then, species were confirmed by the specialist Jhon Cesar Neita Moreno. The collected specimens were deposited in the collections of the Departamento de Biología de los Artrópodos, Universidad Nacional del Nordeste (CARTROUNNE) and in the collections of MACN.

\section{Data analysis}

Sampling efficiency was evaluated using nonparametric estimators: Chao1 and Chao2. A sampling value was considered efficient when the observed species richness was equivalent to $80 \%$ of the estimated richness. Nonparametric estimators were calculated using the program EstimateS 8.0 (Colwell 2006). For each sample year, a rarefaction curve based on the number of individuals was drawn to compare the number of species accumulated between years, standardised to the same sample size (the number of individuals in the community with lower abundance). Rare species were those with fewer than 10 specimens (Colwell 2006).

Diversity was assessed using the effective number of species proposed by Jost (2006). This analysis used the first-order diversity $\left({ }^{l} D\right)$, which is the exponential of the Shannon entropy, and the second-order diversity $\left({ }^{2} D\right)$, which is the inverse of the Simpson index. These measures determine how much the abundant species influence the extent of diversity. In ${ }^{l} D$, all species are included with weights proportional to their abundance in the community, and ${ }^{2} D$ includes only the most abundant species (Gotelli \& Chao 2013). To facilitate comparisons with other studies, the Shannon index was also calculated. To establish the differences in the abundance and richness of the assemblage of beetles collected among different years, a non-parametric Friedman analysis for related samples was performed using InfoStat software (Di Rienzo et al. 2008).

To verify changes in beetle composition among the years, we used a one-way analysis of similarities (ANOSIM) with 10000 permutations (Clarke 1993). The similarity of species between years was measured using the classic Jaccard incidence rate $\left(J_{\text {clas }}\right)$. The Jaccard index based on abundances $\left(J_{a b d}\right)$ and its estimator $\left(\hat{J}_{a b d}\right)$ were also used, as proposed by Chao et al. (2005). According to these authors, in communities with numerous rare species, there is an increased probability that a species present in two sampled assemblages will be collected in one sample but not the other sample, erroneously introducing a negative bias in similarity indices. Chao et al. (2005) referred to these species as unseen shared species. The estimator based on abundances $\left(\hat{J}_{a b d}\right)$ includes the estimated effect of unseen shared species, consistently reducing the bias introduced by subsampling. These analyses were performed with the routine provided in EstimateS 8.0 (Colwell 2006).

A Spearman test was used to analyse whether the abundance ranks of species of each assemblage were correlated among the three years. This test was also used to assess whether the species richness and abundance were related to the environmental variables. Richness and abundance values were each correlated with each environmental variable. These variables were precipitation at 7,14 and 21 days before sampling and values of temperature (maximum, minimum and medium), relative humidity and moonlight percentage registered on the day of collection. These analyses were performed using Past software (Hammer et al. 2014). In all analyses, the $\alpha$ level of significance $\alpha=0.05$ was used.

\section{RESULTS}

We collected a total of 474 individuals belonging to three subfamilies, with 20 genera and 38 species. Dynastinae had the greatest richness ( $\mathrm{S}=17 ; n=108)$ and Rutelinae the largest number of individuals $(\mathrm{S}=13 ; n=265)$, and Melolonthinae was the subfamily with the lowest richness and abundance ( $\mathrm{S}=8, n=101$ ). The best represented genus was Leucothyreus with five species, followed by Bothynus and Liogenys, each with four species. The species Blepharotoma plaumanni Frey 1973 and Plectris setiventris Moser 1918 are new records for Argentina (Table 1).

According to the estimators Chao1 and Chao2, at least 91.7, 86.5 and $73.7 \%$ of the species were captured in 2010, 2011 and 2012, respectively. The estimators suggested that after the three years between 91 and $89.5 \%$ of the species present in the RNECB had been captured (Table 2). Species accumulation curves for the three years showed an approach to the asymptote only in the 2010 sample (Fig. 2).

The total diversity $(\gamma)$ value was 19.2 according to first-order diversity $\left({ }^{1} D\right)$ and 13.6 according to second-order diversity $\left({ }^{2} D\right)$ (Fig. 3a). The highest abundance and species richness was found in 2010, and the greatest diversity was recorded in 2012 (Fig. 3b). According to the accumulation species curve standardised to a size of 113 individuals (Fig. 2), the same richness ( $\mathrm{S}=24$ ) was 


\section{M G Ibarra Polesel and M P Damborsky}

Table 1 Species abundance of Melolonthidae beetles for each sampled year in the RNECB, Chaco, Argentina

\begin{tabular}{|c|c|c|c|c|c|}
\hline \multirow[t]{2}{*}{ Subfamily/Tribe } & \multirow[t]{2}{*}{ Species } & \multicolumn{3}{|c|}{ Years } & \multirow{2}{*}{ Total } \\
\hline & & 2010 & 2011 & 2012 & \\
\hline Dynastinae & - & - & - & - & - \\
\hline \multirow{8}{*}{ Cyclocephalini } & Chalepides luridus (Burmeister, 1847) & - & 2 & 1 & 3 \\
\hline & Cyclocephala metrica Steinheil, 1874 & 3 & 1 & - & 4 \\
\hline & Cyclocephala modesta Burmeinster, 1847 & 1 & - & 5 & 6 \\
\hline & Cyclocephala ochracea Prell, 1937 & 1 & 2 & - & 3 \\
\hline & Dyscinetus dubius (Olivier, 1789) & - & 4 & 3 & 7 \\
\hline & Stenocrates agricola Dechambre y Hardy, 2004 & 29 & - & 8 & 37 \\
\hline & Stenocrates holomelanus (Germar, 1824) & 2 & - & - & 2 \\
\hline & Stenocrates rufipenis (Fabricius, 1801) & 5 & 1 & - & 6 \\
\hline \multirow[t]{5}{*}{ Pentodontini } & Bothynus exaratus (Burmeister, 1847) & 6 & 4 & - & 10 \\
\hline & Bothynus laevipennis Arrow, 1937 & 2 & - & - & 2 \\
\hline & Bothynus cf. minor Steinheil, 1872 & - & - & 1 & 1 \\
\hline & Bothynus striatellus (Fairmaire, 1878) & 1 & 1 & 1 & 3 \\
\hline & Euetheola humilis (Burmeister, 1847) & - & 2 & 12 & 14 \\
\hline \multirow[t]{4}{*}{ Phileurini } & Archophileurus chaconus Kolbe,1910 & 3 & - & 1 & 4 \\
\hline & Phileurus angustatus Kolbe, 1910 & 2 & - & 1 & 3 \\
\hline & Phileurus bucculentus Ohaus, 1911 & 1 & - & - & 1 \\
\hline & Phileurus valgus (Olivier, 1789) & 2 & - & - & 2 \\
\hline Melolonthinae & - & - & - & - & - \\
\hline \multirow[t]{4}{*}{ Diplotaxini } & Liogenys fusca (Blanchard 1851) & 2 & 2 & - & 4 \\
\hline & Liogenys obesina Frey, 1969 & - & - & 4 & 4 \\
\hline & Liogenys suturalis Blanchard, 1851 & 33 & 11 & 13 & 57 \\
\hline & Liogenys tarsalis Moser, 1921 & - & - & 1 & 1 \\
\hline Liparetrini & Blepharotoma plaumanni Frey, 1973 & 2 & - & 3 & 5 \\
\hline \multirow[t]{2}{*}{ Macrodactylini } & Plectris decipiens Burmeister, 1855 & 2 & - & 9 & 11 \\
\hline & Plectris setiventris Moser, 1918 & 1 & - & - & 1 \\
\hline Melolonthini & Phyllophaga conformis (Blanchard,1851) & 2 & 6 & 10 & 18 \\
\hline Rutelinae & - & - & - & - & - \\
\hline Anomalini & Paranomala testaceipennis (Blanchard, 1856) & 6 & - & 1 & 7 \\
\hline \multirow[t]{8}{*}{ Geniatini } & Geniates borelli Camerano, 1891 & 20 & 11 & 3 & 34 \\
\hline & Geniates impressicollis Ohaus, 1911 & 3 & 29 & 4 & 36 \\
\hline & Leucothyreus costatus chaconus Ohaus, 1931 & - & 1 & 5 & 6 \\
\hline & Leucothyreus homonychius Ohaus, 1917 & 12 & - & 1 & 13 \\
\hline & Leucothyreus marginaticollis Blanchard, 1843 & 20 & 4 & 13 & 37 \\
\hline & Leucothyreus mutatus Harold, 1869 & 3 & 1 & 4 & 8 \\
\hline & Leucothyreus sp. & - & 1 & - & 1 \\
\hline & Lobogeniates tucumanensis Camerano, 1891 & 31 & 22 & 7 & 60 \\
\hline \multirow[t]{4}{*}{ Rutelini } & Homonyx planicostatus argentinus (Gutierrez,1952) & 1 & - & - & 1 \\
\hline & Pelidnota fulva Blanchard, 1850 & 32 & 8 & 16 & 56 \\
\hline & Pelidnota richteri (Ohaus, 1910) & 2 & - & 1 & 3 \\
\hline & Strigidia crassipes (Ohaus, 1905) & 3 & - & - & 3 \\
\hline Number of individuals & - & 233 & 113 & 128 & 474 \\
\hline Number of species & - & 30 & 19 & 25 & 38 \\
\hline
\end{tabular}

recorded in 2010 and 2012, and lower richness was recorded in 2011 ( $\mathrm{S}=19$ ). The average numbers of species and individuals per trap were highest in $2010[(\mathrm{~S}=12.8 \pm 4.8)$; $(n=38.3 \pm 15.8)]$ followed by $2012[(\mathrm{~S}=10.5 \pm 2.1)$; $(n=32.0 \pm 5.9)]$ and then $2011[(\mathrm{~S}=9.7 \pm 1.1)$ $(n=28.5 \pm 4.5)]$, with maximum catches in December 2010 ( $\mathrm{S}=17, n=85)$ and minimum in February $2011(\mathrm{~S}=3$, $n=4)$. According to the Friedman test, assemblages differed significantly across the three years, both in richness $\left(T^{2}=3.33\right.$, $P=0.04)$ and in abundance $\left(T^{2}=5.60, P=0.006\right)$ (Fig. 4).

The correlations of the assemblage abundance ranks between sampling years were low and non-significant in any instance [(2011 vs. $\left.2012, \mathrm{r}_{\mathrm{s}}=0.26, P=0.15\right) ;\left(2010\right.$ vs. $2011, \mathrm{r}_{\mathrm{s}}=0.23$, $P=0.18) ;\left(2010\right.$ vs. $\left.\left.2012, \mathrm{r}_{\mathrm{s}}=0.20, P=0.24\right)\right]$. The general rank-abundance curves (Fig. 3a), representing assemblages of each year (Fig. 3b), showed a similar pattern. The assemblages were composed of large numbers of rare species and small numbers of moderately abundant species. In total, rare species represented $69 \%$ of the total richness over all years, $80 \%$ during 2011 and 2012, and a lower proportion in 2010 (77\%).

Table 2 Observed and estimated richness of Melolonthidae beetles (percentage of completeness in parentheses) for each sampled years and all years in the RNECB, Chaco, Argentina

\begin{tabular}{llllll}
\hline & Obs & \multicolumn{2}{c}{ Chao1 } & \multicolumn{2}{c}{ Chao2 } \\
\hline 2010 & 30 & 31.5 & $(95.3 \%)$ & 32.7 & $(91.7 \%)$ \\
2011 & 19 & 22.0 & $(86.5 \%)$ & 21.6 & $(87.8 \%)$ \\
2012 & 25 & 33.9 & $(73.7 \%)$ & 31.5 & $(79.4 \%)$ \\
All 3 years & 38 & 41.8 & $(91.0 \%)$ & 42.4 & $(89.5 \%)$ \\
\hline
\end{tabular}




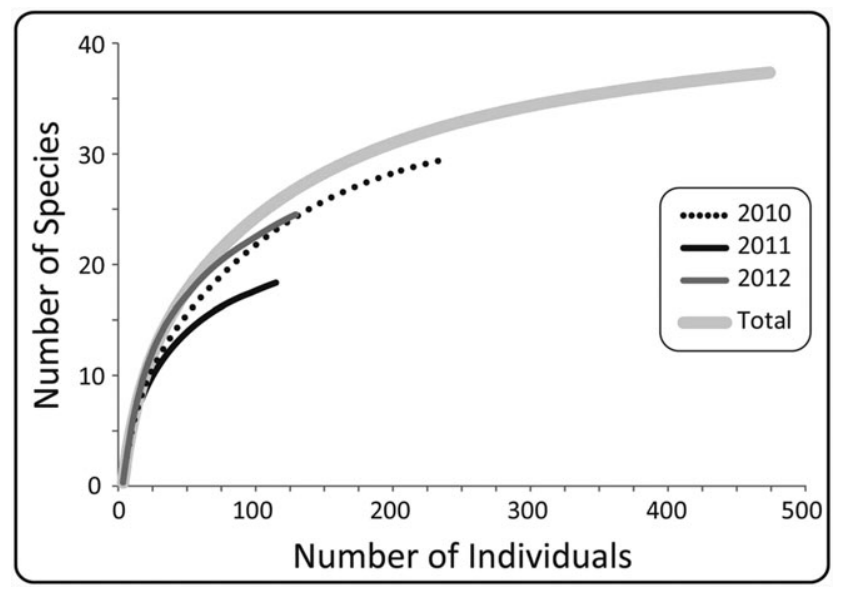

Fig. 2. Species accumulation curves related to the number of individuals of Melolonthidae beetles in the three separate years and during all three years in the RNECB, Chaco, Argentina.

Nevertheless, changes in the distribution of species abundance over the three years were observed. Liogenys suturalis was one of the few species that remained as the most abundant throughout the study (Fig. 3b), unlike Geniates impressicollis, which was a highly abundant species in 2011 and rare in other years. The abundance of Lobogeniates tucumanensis decreased throughout the study, while Stenocrates agricola, one of the most abundant species in 2010, was not collected in 2011 and was rare in 2012.

The similarity analysis (ANOSIM) showed no significant differences in species composition among the three years of the study (Jaccard Index, $R=0.97, P=0.06$ ). The similarity based

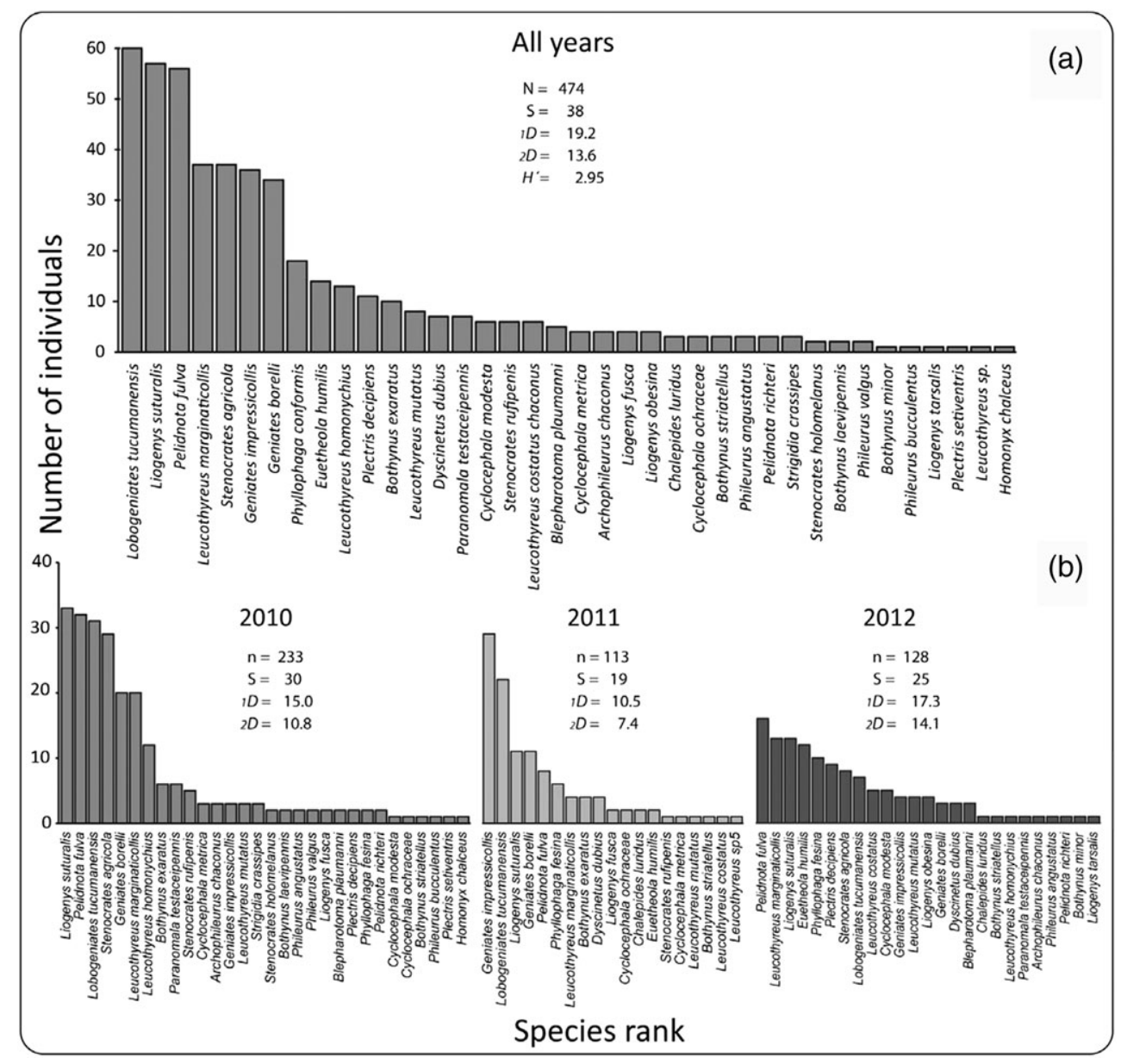

Fig. 3. Rank-abundance curves of Melolonthidae for the entire sampling period and for each sampled year. The graphs show values of abundance (n), richness (S) and true diversity $\left({ }^{1} D,{ }^{2} D\right)$. 


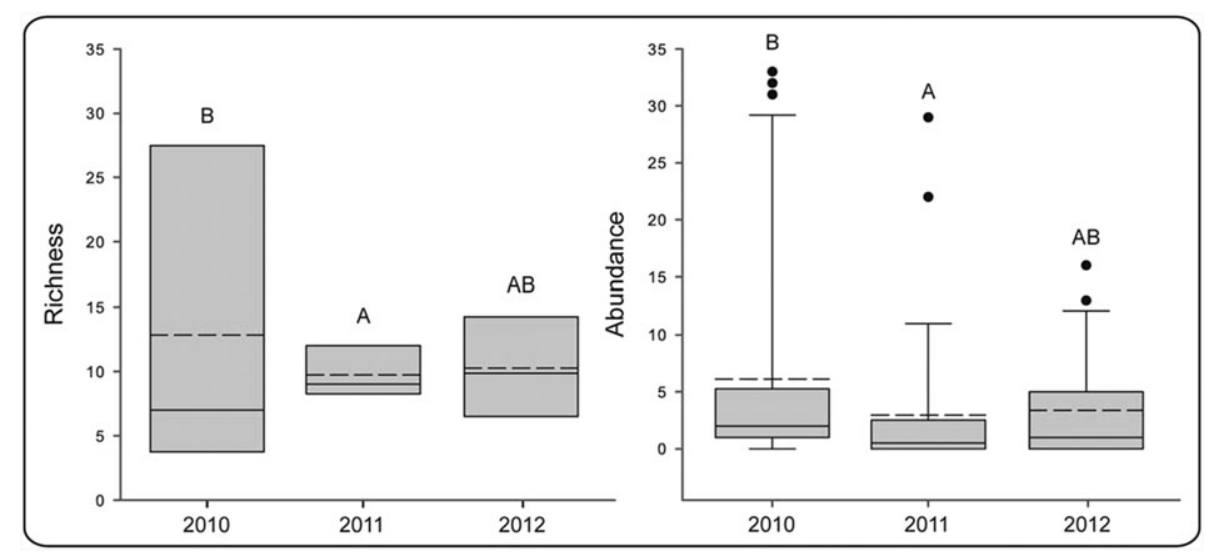

Fig. 4. Richness and abundance of Melolonthidae beetles during three years in the RNECB, Chaco, Argentina. The graphs show the median (solid line), mean (dashed line), 25-75\% quartiles (boxes), atypical values (black dots) and extreme values (whiskers). Values with different letters indicate statistically significant differences according to the Friedman test.

on incidence varied from 40 to $49 \%$ (Fig. 5). The lowest values were observed between the 2010 and 2011 sampled collections; out of the 35 species recorded, only 14 were present in both collections. The similarities based on abundance were observed to be between 66 and $71 \%$, with 2010 and 2012 being the most similar. The inclusion of the estimated effect of unseen shared species resulted in a consistent increase of the similarity between the assemblies $(72-80 \%)$.

Melolonthidae abundance was correlated with the rainfall registered 7 days before $\left(r_{s}=0.81 ; P=0.10\right)$ and with the relative humidity $\left(r_{s}=0.91 ; P=0.03\right)$ (Table 3$)$. In addition, the richness was highly correlated with the mean temperature $\left(r_{s}=0.99\right.$; $P=0.01)$ and the minimum temperature $\left(r_{s}=0.90 ; P=0.05\right)$, followed by the level of rainfall registered 7 days before $\left(r_{s}=0.88\right.$; $P=0.06)$ and the relative humidity $\left(r_{s}=0.85 ; P=0.08\right)$. The annual rainfall was higher in $2010(1517 \mathrm{~mm})$ than in the following years $[(2011=1217 \mathrm{~mm})$ and $(2012=1178.6 \mathrm{~mm})]$, coinciding with the higher average catch per trap in that year.

\section{DISCUSSION}

The richness and diversity of Melolonthidae found in this study were high, considering the small size of the area. The results were similar to those reported by Otavo et al. (2013) in an Amazonian rainforest and by Ronqui and Lopes (2006) in forest fragments in southern Brazil. Likewise, the richness and diversity were higher than recorded in studies in the forests of both Mexico (Reyes-Novelo \& Morón 2005; Yanes-Gómez \& Morón 2010; Lugo et al. 2013; Rivera-Gasperín et al. 2013) and Colombia (Neita et al. 2006; García-Atencia et al. 2015).

Nonparametric estimators indicated a satisfactory catch percentage $(>80 \%)$ for collections from 2010 and 2011. Although the efficiency was lower in 2012, the diversity values were higher. Furthermore, the pattern that characterised the structure of the three assemblages included a large number of rare species associated with few abundant species, a pattern that has also been reported in other studies of the Melolonthidae

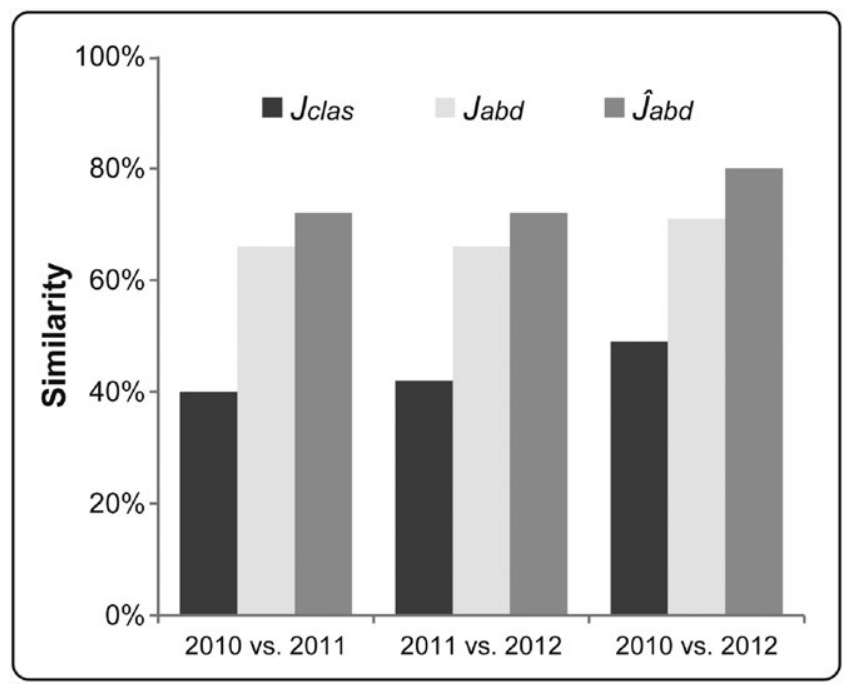

Fig. 5. Compositional similarity of Melolonthidae species among three years. Results are shown for the classic Jaccard index $\left(J_{\text {clas }}\right)$, the abundance-based Jaccard index $\left(J_{a b d}\right)$ and the abundance-based Jaccard estimator, which accounts for unseen species $\left(\hat{J}_{a b d}\right)$. 
Table 3 Correlation between species richness and abundance against environmental variables over the three years of study in the RNECB, Chaco, Argentina

\begin{tabular}{lllll}
\hline Environmental variables & \multicolumn{2}{c}{ Species } & \multicolumn{2}{c}{ Individuals } \\
\hline & $r s$ & $P$ & $r s$ & $P$ \\
\hline Precipitation & - & - & - & - \\
7 days before sampling & 0.88 & 0.06 & 0.81 & 0.10 \\
14 days before sampling & 0.24 & 0.44 & 0.52 & 0.25 \\
21 days before sampling & 0.24 & 0.44 & 0.39 & 0.32 \\
Temperature & - & - & - & - \\
Maximum & 0.54 & 0.24 & 0.36 & 0.35 \\
Minimum & 0.90 & 0.05 & 0.36 & 0.35 \\
Medium & 0.99 & 0.01 & 0.36 & 0.33 \\
Relative humidity & 0.85 & 0.08 & 0.91 & 0.03 \\
Moonlight percentage & 0.67 & 0.17 & 0.52 & 0.25 \\
\hline
\end{tabular}

(Moron \& Deloya 1991; Ronqui \& Lopes 2006; Delgado et al. 2012; Otavo et al. 2013; García-Atencia et al. 2015).

Regarding the first question asked in this study, our results indicate that the distribution of species abundance was highly variable over time, mainly in those species that presented larger numbers of individuals. The species that were abundant in one year were recorded in smaller quantities in another year (e.g. Geniates borelli, Geniates impressicollis, Lobogeniates tucumanensis and Pelidnota fulva) or were not captured (Stenocrates agricola and Leucothyreus homonychius). These results suggest that in the subtropical region, Melolonthidae assemblages can be significantly dynamic in terms of species abundance, even over short periods of time. Buss (2006) studied Melolonthidae beetles in open areas, and although those data indicated fluctuations in the abundance of most species over three years, the composition of the assemblage was consistent over time.

Similarly, in a study of dung beetles in Mexico, Halffter et al. (2007) compared sample collections separated by several years (4 to 12 years) and found that the variation in the distribution of the abundances of species over time was remarkable in forests and much lower in grasslands. Other studies that addressed the changes in the abundance distribution of beetles over time found similar results (Moron \& Deloya 1991; Allsopp \& Logan 1999; Howden \& Howden 2001; Quintero \& Roslin 2005; Escobar et al. 2008; Agoglitta et al. 2012).

Regarding the above, Halffter et al. (2007) stated that one aspect to consider in a community is the temporal variation in the distribution of species abundance, as a species may be rare or even absent at one point in time and then abundant at another. This variation has a marked effect on the expression of the results, considering that sampling at one time may overstate the differences between assemblages, but these differences may disappear when the study is conducted during two or more moments in a given period. In terms of our results, if the study period had been restricted to 2011, the most abundant species of Melolonthidae would have been $G$. impressicollis, and the assembly would have had an intermediate richness, which may have been only partially true.

Most studies on beetles that address temporal beta diversity report a high turnover of species over time. Agoglitta et al.
(2012) measured higher temporal than spatial turnover values in one study location. Furthermore, Escobar et al. (2008) reported that the similarity between beetle assemblages declines as the time interval increases between surveys. In contrast, Halffter et al. (2007) found that the species turnover increases as the heterogeneity of the environment increases and recorded the highest values of turnover in forests, intermediate turnover in coffee plantations and the lowest turnover in grasslands. High values of replacement have also been reported for Melolonthidae beetles (Moron \& Deloya 1991; García-López et al. 2010).

Regarding the second question asked in our study, the turnover values calculated by the three indices $\left(J_{\text {clas }}, J_{a b d}\right.$ and $\hat{J}_{a b d}$ ) were variable. The low similarity obtained from $J_{\text {clas }}$ may result from the large number of rare species, given that many such species are represented by small populations that are randomly caught (Halffter \& Moreno 2005). The similarity values of abundance $\left(J_{a b d}\right)$ were intermediate, and the highest values were obtained from the estimator $\hat{J}_{a b d}$, indicating a seemingly lower turnover than calculated by the other indices $\left(J_{\text {clas }}\right.$ and $\left.J_{a b d}\right)$. This result suggests that the missing species would still be present in the RNECB and not captured only because they were not attracted to the traps. In contrast, other surveys conducted over longer study periods suggest that the absence could be a result of the loss of local species.

Regarding the last question asked in this study, the abundance and richness of Melolonthidae were correlated with the relative humidity, the rainfall registered seven days before, and the average and minimum temperatures. Útima and Vallejo (2008), Delgado et al. (2012) and García-Atencia et al. (2015) have also reported correlations of Melolonthidae abundance and richness with some of these variables. According to Morón (1997), temperature and humidity most frequently determine the presence of one or another species, although it is possible that $\mathrm{pH}$ and soil texture are also significantly important for the establishment and development of larvae. These and other environmental variables could also influence the beetle community, but unfortunately, they have not been measured. The highest levels of rainfall were recorded in 2010, which corresponded to the highest average catch per trap. Howden and Howden (2001) associate the decline in the number of species over time with two factors: competitive changes due to the introduction of exotic species and climate change, mainly due to the rainfall that produces changes in vegetation. However, Pianka (1982) proposes that many communities may be supersaturated with species without competitive exclusion between them, because the climate changes and sudden disturbances (periods of cold, drought, inundation etc.) are responsible for the regulation of population sizes. Our findings support Pianka's hypothesis in which the environmental variables are the most important change factors in the assemblages from year to year.

The high richness of beetle assemblages has been attributed to lower levels of disturbance, high complexity of the ecosystem and good vegetation cover (Halffter \& Arellano 2002; Favila 2005; Delgado et al. 2012; Hernández et al. 2014; Damborsky et al. 2015; Menegaz de Farias et al. 2015). We could infer based on the results obtained, that the RNECB is a well preserved 
fragment of native gallery forest and has a high ecological value. Studies on other taxa in this reserve, such as Formicidae (Gómez-Lutz \& Godoy 2010), Araneae (Escobar et al. 2012) and Isoptera (Godoy et al. 2013) have yielded similar results.

However, the high richness in forest fragments may be due to the arrival of beetles from the surrounding environments as a result of an edge effect, as some studies have reported (Favila 2005; Pineda et al. 2005; Peyras et al. 2013; Otavo et al. 2013). In a study in a Costa Rican reserve over three time periods (1969, 1993 and 2004), Escobar et al. (2008) observed significant changes in the composition of the Scarabaeinae community and suggested that those changes resulted in part from habitat loss from areas near the reserve. In our case, the RNECB has been reduced to a small island surrounded by pastures used for livestock, and it is highly permeable to common species from other areas that migrate to the forest. Ibarra-Polesel et al. (2015) found species of dung beetles common to open areas inside the RNECB. According to Halffter and Moreno (2005), these species, called tourists, are the ones that stochastically reach the sampling area.

Some of the collected species (Cyclocephala modesta, Bothynus striatellus, Archophileurus chaconus, Liogenys fusca, Liogenys suturalis and Paranomala testaceipennis) are agricultural pests in the region (Frana 2007; Bonivardo et al. 2013) and could be considered tourist species because they are frequent in the open agro-environments with high sunlight exposure. However, Cherman et al. (2014) found a high density of Melolonthidae species considered nuisance species in wilderness areas. That study suggested that the high density was because of the large ecological amplitude of these species. Therefore, the question remains whether these species are acting as tourists or whether they live and grow in the forest because of their ecological amplitude.

Finally, because indicator groups do not always respond in the same way, this study provides another perspective on the biodiversity and conservation status of the RNECB. IbarraPolesel et al. (2015) found an intermediate richness of dung beetles (Scarabaeinae) in this area and attributed that result to the small number of mammals in the reserve. Similarly, the high richness of phytophagous beetles from the Melolonthidae family recorded in this study may be attributable to the high number of plant species. The effect of tourist species associated with the areas surrounding the reserve may be significant and may potentially operate in the same way for both the dung beetle and phytophagous assemblages. Studying various indicator groups may provide different results (Halffter \& Moreno 2005; Pineda et al. 2005; Halffter et al. 2007) but may also lead to a more comprehensive, complementary and accurate view of the environmental state.

While this work lays the basis for future studies of Argentine melolonthids and their use as bioindicators in conservation research, many of the results have generated further questions. It is necessary to conduct similar studies in other environments, such as larger forests, given the edge effect of the reduced areas, as well as in pastures to determine which species are behaving as tourists. The techniques used in the collection should also be considered. Although light traps are widely used in diversity studies and represent one of the most efficient methods for the capture of Melolonthidae, the use of complementary capture techniques may reduce the number of rare species and increase the inventory by capturing non-phototropic species. Further, a larger number of traps would surely also help decrease the proportion of rare species captured. Many aspects of this study were compared with studies on dung beetles (Scarabaeinae) due to the wider variety and development of ecological studies on that taxon. However, we must emphasise that the two groups of beetles differ considerably in terms of life cycles and eating habits.

In conclusion, our results suggest that the Melolonthidae assemblage can be considerably dynamic in the small wooded areas of the Argentine subtropics, even over relatively short periods of time. Rare species play an important role in analyses of the similarities between assemblages and could suggest exaggerated turnover rates if we only consider similarity indices based on incidence. Some climatic variables play important roles in the collection of Melolonthidae. The high richness and diversity found in the RNECB may be due to the robust condition of the reserve or to the small area of the RNECB, which may be affected by the surrounding environment, making it permeable to the entry of species from adjacent areas.

\section{ACKNOWLEDGMENTS}

We are grateful to Alicia Guadalupe Poi for the invaluable help in the critical reading of the manuscript. Jhon Cesar Neita provided assistance on species confirmation. We thank Arturo Roig Alcina for the hospitality during the visit to MACN, and Gilberto Avalos provided assistance with the field work. The first author is grateful to CONICET-UNNE, for the grant awarded for postgraduate studies. We thank the National Parks Administration for research permits. This study was funded by Secretaria General de Ciencia y Técnica - Universidad Nacional del Nordeste (Project 17/F174) and Agencia Nacional de Promoción Científica y Técnica (PICTo - UNNE 11-0244). The authors declare no conflict of interest.

\section{REFERENCES}

Agoglitta R, Moreno CE, Rossini M, Tonelli M \& Rica C. 2012. Variación temporal en la diversidad y composición de una comunidad coprófila del euromediterráneo (Coleoptera: Scarabaeoidea). Interciencia 37, 44-48.

Allsopp P \& Logan D. 1999. Seasonal flight activity of scarab beetles (Coleoptera: Scarabaeidae) associated with sugarcane in southern Queensland. Australian Journal of Entomology 38, 219-226.

Anderson MJ, Crist TO, Chase JM et al. 2011. Navigating the multiple meanings of $\beta$ diversity: a roadmap for the practicing ecologist. Ecology Letters 14, 19-28.

Basterra NI, Valientea MÁ \& Pellegrinoa LA. 2013. Humedales de los cursos encajados del abanico Bermejo-Pilcomayo. In: Inventario de los humedales de Argentina: sistemas de paisajes de humedales del corredor fluvial Paraná Paraguay (ed L Benzaquén), pp. 95-102. Secretaría de Ambiente y Desarrollo Sustentable de la Nación, Buenos Aires.

Bonivardo SL, Martínez AN, Funes MB, Suarez A \& Perassi G. 2013. Determinación de especies de gusanos blancos (Coleóptera: 
Scarabaeidae) presentes en lotes de pastizal natural, pasto llorón y cultivados, de la Provincia de San Luis. Revista de la Facultad de Agronomía UNLPam 22, 7-12.

Braby MF \& Williams MR. 2016. Biosystematics and conservation biology: critical scientific disciplines for the management of insect biological diversity. Austral Entomology 55, 1-17.

Brown KS. 1997. Diversity, disturbance, and sustainable use of Neotropical forests: insects as indicators for conservation monitoring. Journal of Insect Conservation 1, 25-42.

Buss EA. 2006. Flight activity and relative abundance of Phytophagous Scarabs (Coleoptera: Scarabaeoidea) from two locations in Florida. The Florida Entomologist 89, 32-40.

Calderón-Patrón JM \& Moreno CE. 2012. La diversidad beta: medio siglo de avances. Revista Mexicana de Biodiversidad 83, 879-891.

Chao A, Chazdon RL \& Shen TJ. 2005. A new statistical approach for assessing similarity of species composition with incidence and abundance data. Ecology Letters 8, 148-159.

Chebez JC. 2005. Guía de las reservas naturales de la Argentina: Nordeste. Editorial Albatros, Buenos Aires, Argentina.

Cherman MA \& Morón MÁ. 2014. Validación de la Familia Melolonthidae. Acta Zoologica Mexicana 30, 201-220.

Cherman MA, Morón MÁ, Salvadori JR, Dal Prá E \& Carús Guedes JV. 2014. Análise populacional de corós-praga e de outras espécies no planalto do Rio Grande do Sul. Ciência Rural 44, 2095-2102.

Clarke KR. 1993. Non-parametric multivariate analysis of changes in community structure. Australian Journal of Ecology 3, 117-143.

Colwell RK. 2006. EstimateS: statistical estimation of species richness and shared species from samples, Versión 8.

Cuadra DE. 2012. La problemática forestal en la provincia del Chaco, Argentina. Un análisis desde la Geografía. Revista Geográfica Digital. IGUNNE. Facultad de Humanidades. UNNE 9, 1-25.

Damborsky MP, Alvarez Bohle MC, Ibarra Polesel MG, Porcel EA \& Fontana JL. 2015. Spatial and temporal variation of dung beetle assemblages in a fragmented landscape at eastern humid Chaco. Neotropical Entomology 44, 30-39.

Delgado JM, Castro-Ramírez AE, Morón MÁ \& Ruiz-Montoya L. 2012. Diversidad de Scarabaeoidea (Coleoptera) en las principales condiciones de hábitat de Montebello, Chiapas, México. Acta Zoologica Mexicana 28, $185-210$.

Di Rienzo JA, Casanoves F, Balzarini MG, Gonzalez L, Tablada M \& Robledo CW. 2008. InfoStat: Grupo InfoStat, FCA, Universidad Nacional de Córdoba, Argentina, versión 2008.

Endrödi S. 1966. Monographie der Dynastinae (Col. Lam.) I. Teil. Entomologische Abhandlungen Museum Tierkunde, Dresden 33, 1-457.

Escobar F, Halffter G, Solís Á, Halffter V, Navarrete D \& Rica C. 2008. Temporal shifts in dung beetle community structure within a protected area of tropical wet forest: a 35-year study and its implications for long-term conservation. Journal of Applied Ecology 45, 1584-1592.

Escobar MJ, Ávalos G \& Damborsky MP. 2012. Diversidad de Araneae (Arachnida) en la Reserva Colonia Benítez Chaco Oriental Húmedo, Argentina. Facena 28, 3-17.

Favila ME. 2005. Diversidad alfa y beta de los escarabajos del estiércol (Scarabaeinae) en Los Tuxtlas México. In: Sobre diversidad biológica: el significado de las diversidades alfa, beta y gamma (eds G Halffter, J Soberón, P Koleff \& A Melic), pp. 209-219. M3mmonografías tercer milenio, Zaragoza.

Favila ME \& Halffter G. 1997. The use of indicator groups for measuring biodiversity as related to community structure and function. Acta Zoologica Mexicana 72, 1-25.

Frana J. 2007. Evaluación de insecticidas aplicados a la semilla de trigo y en cobertura total para el control de gusano blanco. Publicación Miscelánea. INTA Rafaela, Argentina 107, 90-95.

García-Atencia S, Martínez-Hernández N \& Pardo-Locarno LC. 2015. Escarabajos fitófagos (Coleoptera: Scarabaeidae) en un fragmento de bosque seco tropical del departamento del Atlántico, Colombia. Revista Mexicana de Biodiversidad 86, 754-763.

García-López A, Micó E, Numa C \& Galante E. 2010. Spatiotemporal variation of scarab beetle assemblages (Coleoptera: Scarabaeidae: Dynastinae, Melolonthinae, Rutelinae) in the Premontane Rain Forest in Costa Rica: a question of scale. Entomological Society of America 103, 956-964.
Ginzburg R \& Adámoli J. 2006. Situación ambiental en el Chaco Húmedo. In: La situación Ambiental Argentina 2005 (eds A Brown, U Martínez, M Ortiz Acerb \& J Corcuera), pp. 103-113. Fundación Vida Silvestre, Buenos Aires.

Godoy MC, Laffont ER, Coronel JM \& Etcheverry C. 2013. Termite (Insecta Isoptera) assemblage of a gallery forest relic from the Chaco province (Argentina): taxonomic and functional groups. Arxius de Miscellània Zoològica 10, 55-67.

Gómez-Lutz MC \& Godoy MC. 2010. Diversidad y grupos funcionales de Formicidae (Insecta, Hymenoptera) de la reserva natural educativa Colonia Benítez (provincia del Chaco, Argentina). Revista FABICIB 14, 180-195.

Gotelli NJ \& Chao A. 2013. Measuring and estimating species richness, species diversity, and biotic similarity from sampling data. Encyclopedia of Biodiversity 5, 608-625.

Halffter G \& Arellano L. 2002. Response of dung beetle diversity to humaninduced changes in a tropical landscape. Biotropica 34, 144-154.

Halffter G \& Favila ME. 1993. The Scarabaeidae (Insecta: Coleoptera) an animal group for analysing, inventoryng and monitoring biodiversity in tropical rainforest and modified landscapes. Biology International 27, $1-21$.

Halffter G \& Moreno CE. 2005. Significado biológico de las Diversidades Alfa, Beta y Gamma. m3m: Monografias Tercer Milenio 4, 5-18.

Halffter G, Pineda E, Arellano L \& Escobar F. 2007. Instability of copronecrophagous beetle assemblages (Coleoptera: Scarabaeinae) in a mountainous tropical landscape of Mexico. Entomological Society of America 36, 1397-1407.

Hammer O, Harper DA \& Ryan PD. 2014. PAST: paleontological statistics software package for education and data analysis, version 9 .

Hernández MIM, Barreto PSCS, Costa VH, Creao-Duarte AJ \& Favila ME. 2014. Response of a dung beetle assemblage along a reforestation gradient in Restinga forest. Journal of Insect Conservation 18, 539-546.

Howden H \& Howden A. 2001. Change through time: a third survey of the scarabaeinae (Coleoptera: Scarabaeidae) at Welder Wildlife Refuge. The Coleopterists Bulletin 55, 356-362.

Ibarra-Polesel MG, Damborsky MP \& Porcel E. 2015. Escarabajos copronecrófagos (Scarabaeidae: Scarabaeinae) de la Reserva Natural Educativa Colonia Benítez, Chaco, Argentina. Revista Mexicana de Biodiversidad 78, 459-482.

INTA. 2015. SIGA - Sistema de Información y Gestión Agrometeorológico. Instituto Nacional de Tecnología Agropecuaria (INTA). [Accessed 23 Nov 2015.] Available from URL: http://siga2.inta.gov.ar/en/datos historicos/

Jost L. 2006. Entropy and diversity. Oikos 113, 363-375.

Ledesma LL. 1995. Carta de Suelos de la Estación Experimental Agropecuaria Colonia Benitez "Dr. Agusto G. Schulz" Provincia del Chaco. Instituto Nacional de Tecnología Agropecuaria - EEA - Sáenz Peña, Pres. Roque Saenz Peña, Chaco.

Lugo G, Morón MA, Aragón A, Ortega L, Reyes-Olivas A \& Sánchez B. 2013. Especies nocturnas de Scarabaeoidea (Coleoptera: Polyphaga) en el norte de Sinaloa, México. Revista Colombiana de Entomologia 39, 95-104.

Magurran AE. 2004. Measuring Biological Diversity. Blackwell Science, Oxford.

McGeoch MA, Van Rensburg BJ \& Botes A. 2002. The verification and application of bioindicators: a case study of dung beetles in a savanna ecosystem. Journal of Applied Ecology 39, 661-672.

Menegaz de Farias P, Arellano L, Hernández MIM \& López OS. 2015. Response of the copro-necrophagous beetle (Coleoptera: Scarabaeinae) assemblage to a range of soil characteristics and livestock management in a tropical landscape. Journal of Insect Conservation 19, 947-960.

Morón MÁ. 1997. Inventarios faunisticos de los Coleoptera Melolonthidae Neotropicales con potencial como bioindicadores. Giornale Italiano di Entomologia 8, 265-274.

Moron MA \& Deloya C. 1991. Los Coleopteros Lamelicornios de la Reserva de la Biosfera "La Michilia", Durango, México. Folia Entomológica Mexicana 81, 209-283.

Neita JC, Orozco J \& Ratcliffe BC. 2006. Escarabajos (Scarabaeidae: Pleurosticti) de la selva baja del bosque pluvial tropical «BP-T», Chocó, Colombia. Acta Zoologica Mexicana 22, 1-32.

Noss RF. 1990. Indicators for monitoring biodiversity: a hierarchical approach. Conservation Biology 4, 355-364. 


\section{I0 M G Ibarra Polesel and M P Damborsky}

Otavo SE, Parrado-Rosselli Á \& Noriega JA. 2013. Superfamilia Scarabaeoidea (Insecta: Coleoptera) como elemento bioindicador de perturbación antropogénica en un parque nacional amazónico. Revista de Biología Tropical 61, 735-752.

Pardo-Locarno LC. 2013. Escarabajos (Coleoptera: Melolonthidae) del plan aluvial del Rio Cauca, Colombia I. Ensamblaje, fichas bioecológicas, extinciones locales y clave para adultos. Dugesiana 20, 1-15.

Peyras M, Vespa NI, Bellocq MI \& Zurita GA. 2013. Quantifying edge effects: the role of habitat contrast and species specialization. Journal of Insect Conservation 17, 807-820.

Pianka ER. 1982. Ecologia Evolutiva. Spanish Translation of Second Edition of Evolutionary Ecology. Ediciones Omega, Barcelona, Spain.

Pineda E, Moreno C, Escobar F \& Halffter G. 2005. Frog, bat, and dung beetle diversity in the cloud forest and coffee agroecosystems of Veracruz, Mexico. Conservation Biology 19, 400-410.

Quintero I \& Roslin T. 2005. Rapid recovery of dung beetle communities following habitat fragmentation in Central Amazonia. Ecology 86, 3303-3311.

Reyes-Novelo E \& Morón MÁ. 2005. Fauna de Coleoptera Melolonthidae y Passalidae de Tzucacab y Conkal, Yucatán, México. Acta Zoologica Mexicana 21, 15-49.
Rivera-Gasperín SL, Carrillo-Ruiz H, Morón MÁ \& Yanes-Gómez G. 2013. Fauna de Coleoptera Melolonthidae (Scarabaeoidea) en el Rancho Canaletas, Paso del Macho, Veracruz, México. Acta Zoologica Mexicana 29, 194-208.

Ronqui DC \& Lopes J. 2006. Composição e diversidade de Scarabaeoidea (Coleoptera) atraídos por armadilha de luz em área rural no norte do Paraná, Brasil. Iheringia. Série Zoologia 96, 103-108.

Steinbauer MJ \& Weir TA. 2007. Summer activity patterns of nocturnal Scarabaeoidea (Coleoptera) of the southern tablelands of New South Wales. Australian Journal of Entomology 46, 7-16.

Útima O \& Vallejo LF. 2008. Escarabajos Melolonthidae (ScarabaeidaePleurosticti) de la montaña cafetera, departamento de Risaralda, Colombia. Agronómica 16, 31-44.

Whittaker RH. 1972. Evolution and measurement of species diversity. Taxon 12, 213-251.

Yanes-Gómez G \& Morón MA. 2010. Fauna de coleópteros Scarabaeoidea de Santo Domingo Huehuetlán, Puebla, México. Su potencial como indicadores ecológicos. Acta Zoologica Mexicana 26, 123-145.

Accepted for publication 28 April 2017 